\title{
Kişi-Örgüt Uyumunun İşle Bütünleşme Üzerindeki Etkisi (The Impact of Person-Organization Fit on Work Engagement)
}

\section{Emine GENÇ}

a Bartın Üniversitesi, İktisadi ve İdari Bilimler Fakültesi, Uluslararası Ticaret ve Lojistik Bölümü, Bartın, Türkiye. egenc@bartin.edu.tr

\begin{tabular}{ll}
\hline MAKALE BÍLGisi & ÖZET \\
\hline Anahtar Kelimeler: & Amaç - Kişi ve örgüt karşılıklı olarak etkileşim içerisinde olduğu için kişi-örgüt uyumu bireysel ve \\
Kişi-Örgüt Uyumu & örgütsel performansın sağlanmasında büyük önem taşımaktadır. İnsan kaynağının etkili ve \\
İşle Bütünleşme & verimli çalışması dolayısıyla örgütsel amaçlara ulaşıllmasında önemli olan bir değişken de işle \\
Hizmet Sektörü & bütünleşme kavramıdır. Bu çalışmanın amacı, kişi-örgüt uyumunun işle bütünleşme üzerindeki \\
& etkisinin ve çalışanların kişi-örgüt uyumu ile işle bütünleşme düzeylerinin bazı değişkenlere göre \\
& farklılaşıp farklılaşmadığının incelenmesidir.
\end{tabular}

Gönderilme Tarihi 3 Haziran 2020

Revizyon Tarihi 10 Eylül 2020

Kabul Tarihi 20 Eylül 2020

Makale Kategorisi:

Araştırma Makalesi

Yöntem - Araştırma kantitatif yöntemlerden anket tekniği kullanılarak gerçekleştirilmiştir. İlişkisel tarama modelinin kullanıldığı bu çalışmada Ankara İli'nde hizmet sektöründe özel işletme çalışanı 411 kişiden sağlıklı veri toplanmıştır. Araştırmada kullanılan ölçeklerin yapı geçerliliği ve güvenilirliliği doğrulayıcı faktör analizi (DFA) ile, yakınsak geçerliliği (AVE), birleşim güvenilirliği (CR) ve Cronbach alfa kat sayıları hesaplanarak sınanmıştır. Hipotezlerin test edilmesinde yapısal eşitlik modelinde yol analizi, bağımsız örneklemlerde $t$ testi ve tek yönlü varyans analizinden yararlanılmıştır.

Bulgular - Araştırma sonucunda çalışanların kişi-örgüt uyumu düzeylerinin çalışanların zindelik, adanma ve yoğunlaşma düzeylerini pozitif yönde ve anlamlı bir şekilde etkilediği tespit edilmiştir. Ayrıca çalışanların cinsiyetleri ile kişi-örgüt uyumu ve adanma düzeyleri arasında, eğitim durumları ile kişi-örgüt uyumu, zindelik, adanma ve yoğunlaşma düzeyleri ve çalışma süreleri ile adanma ve yoğunlaşma düzeyleri arasında anlamlı farklılık olduğu bulgulanmıştır.

Tartışma - Araştırmada literatürle uyumlu olarak kişi-örgüt uyumunun işle bütünleşmeyi etkileyen önemli bir değişken olduğu sonucuna ulaşılmıştır. Ayrıca çalışanların demografik değişkenlerinin kişi-örgüt uyumu ve işle bütünleşme düzeyi üzerinde etkili olduğu tespit edilmiştir.

\begin{tabular}{|c|c|}
\hline ARTICLE INFO & ABSTRACT \\
\hline $\begin{array}{l}\text { Keywords: } \\
\text { Person-Organization Fit } \\
\text { Work Engagement }\end{array}$ & $\begin{array}{l}\text { Purpose - Since the person and organization are interacting with each other, person-organization } \\
\text { fit is of great importance in ensuring individual and organizational performance. An important } \\
\text { variable in achieving organizational goals due to the effective and efficient work of human } \\
\text { resource is the concept of work engagement. The purpose of this study is to examine whether the } \\
\text { effect of person-organization fit on work engagement and whether the level of person-organization } \\
\text { fit and work engagement differ according to some variables. }\end{array}$ \\
\hline $\begin{array}{l}\text { Received } 3 \text { June } 2020 \\
\text { Revised } 10 \text { September } 2020 \\
\text { Accepted } 20 \text { September } 2020\end{array}$ & $\begin{array}{l}\text { Design/methodology/approach - The research was carried out by using the survey technique, } \\
\text { which is one of the quantitative methods. In this study, which uses the relational screening model, } \\
\text { healthy data was collected from } 411 \text { privade sector employees in the service sector in Ankara. The } \\
\text { construct validity and reliability of the scales used in the study were tested by confirmatory factor } \\
\text { analysis (CFA), convergent validity (AVE), combination reliability (CR) and Cronbach alpha } \\
\text { coefficients. In testing hypotheses, path analysis in the structural equation model, Independent-t } \\
\text { test and one-way anova were used. }\end{array}$ \\
\hline \multirow[t]{2}{*}{ Research Article } & $\begin{array}{l}\text { Findings - As a result of the research, it was determined that the person-organization fit levels of } \\
\text { the employees positively and significantly affect the vigor, dedication and absorption levels of the } \\
\text { employees. In addition, it was found that there was a significant difference between the sexes of } \\
\text { the employees and the level of person-organization fit and dedication, between their educational } \\
\text { status and person-organization fit, vigor, dedication and absorption levels, and their working time } \\
\text { and dedication and absorption levels. }\end{array}$ \\
\hline & $\begin{array}{l}\text { Discussion - In accordance with literature, it was concluded that person-organization fit is an } \\
\text { important variabla affecting work engagement. In addition, it has been determined that the } \\
\text { demographic variable of the employees are affective on the level of person-organization fit and } \\
\text { work engagement. }\end{array}$ \\
\hline
\end{tabular}

\section{Önerilen Atıf/Suggested Citation}

Genç, E. (2020). Kişi-Örgüt Uyumunun İşle Bütünleşme Üzerindeki Etkisi, İşletme Araştırmaları Dergisi, 12 (3), 3110-3123. 


\section{GíRiş}

Örgütsel başarının yakalanması ve güçlendirilmesinde örgütün en önemli kaynaklarından biri insan kaynağıdır. Örgütsel araştırmalar, çalışanların performanslarını etkileyen değişkenler üzerinde yoğunlaşmaktadır. Birey ile örgüt arasında yaşanan uyum eksikliği, kişide işe ve örgüte karşı negatif tutum ve davranışlar oluşturacağı için kişinin performans düşüklüğü yaşaması kaçınılmaz olacaktır. Uyumsuzluğun yaşandığı durumlarda kişisel ve örgütsel düzeyde önemli olumsuz sonuçlar ortaya çıkabilmektedir.

Zaman içerisinde önemi giderek artan kişi-örgüt uyumu kavramı, modern örgütlerin oldukça önemsedikleri bir kavram haline gelmiştir. Bu doğrultuda örgütler kendileri ile uyumlu bireyleri bünyelerine katma çabası içerisine girmişlerdir. Rynes vd. (2002: 96) de ifade ettiği gibi, personel seçim kararlarında aday ve örgütün uyumluluk düzeyi önemli bir kriter olmaya başlamıştır. Yapılan araştırmalar kişi-örgüt uyumunun işten ayrılma niyeti (Peng vd., 2014; Jin vd., 2018; Zhang vd., 2005), örgütsel sinizm (Aksay ve Yasim, 2016) gibi negatif iş tutum davranışlarının etkisini azalttığını, iş tatmini (Cable ve Judge, 1994; Bayramlık vd., 2015; Ulutaş vd., 2015; Leung ve Chaturvedi, 2011), örgütsel bağıllılı (Greguras ve Diefendorff, 2009; Ulutaş vd., 2015; Yücel ve Çetinkaya, 2016; Leung ve Chaturvedi, 2011) , işle bütünleşme (Sortheix vd., 2013; Rahmadani ve Sebayang, 2017; Hamid ve Yahya, 2011; Peng vd., 2014) gibi pozitif iş tutum davranışlarının etkisini arttırdığını ortaya koymaktadır.

Çalışanların etkili ve verimli çalışabilmeleri konusunda uyum ile beraber önemli rol oynayan diğer bir faktör işle bütünleşme düzeyleridir. Schaufeli ve Bakker (2004:295) işle bütünleşmeyi yüksek düzeyde enerji, özveri ve kendini adama ile karakterize olunan olumlu, tatmin edici, zihinsel bir durum olarak tanımlamaktadır. İşle bütünleşme, örgütlerin yüksek işgücü verimliliği, iş tatmini, düşük personel devir oranı, müşteri memnuniyeti, sadakat ve karlılık gibi konularda rekabet avantajı sağlayan kritik öneme sahip bir faktördür (Rahmadani ve Sebayang ,2017:45).

Bu çalışmada kişi-örgüt uyumunun işle bütünleşme üzerindeki etkisi ve çalışanların kişi-örgüt uyumu ile işle bütünleşme düzeylerinin bazı değişkenlere göre farklılaşıp farklılaşmadığı incelenmiştir. Kişi-örgüt uyumu değişkeni bir çok araştırmaya olsa da işle bütünleşme değişkenine etkisi bağlamında az sayıda çalışılmış çalışılmışır. Bu anlamda çalışmanın literatüre katkı sağlaması beklenmektedir.

\section{LITERATÜR TARAMASI}

\subsection{Kişi-Örgüt Uyumu}

Örgütsel davranış araştırmalarında kişi-örgüt uyumu, kişi ve örgüt değişkenleri karşıllklı olarak birbirini etkilediği için gerek teoride gerekse uygulamada önemli bir yere sahiptir (Baransel, 1979:218). Kişi-örgüt uyumu kavramı, kişi-çevre uyumunun bir alt boyutu (Turunç ve Çelik, 2012: 61) ve kişi-iş uyumunun genişletilmiş halidir (Akbaş, 2011:57). Kişi-örgüt uyumu, kişi ile organizasyonun bir bütün olarak uyumuna odaklanmaktadır (Kim, 2012:832). Kişi-örgüt uyumu, çalışanların değerleri, hedefleri, kişisel özellikleri ve davranışları gibi sahip oldukları kişisel olgular ile kurumun sahip olduğu kültür, değer, hedef gibi örgütsel olguların arasında gerçekleştirilecek olan uyumu ifade etmektedir (Chatman, 1991:339). Cable ve Judge (1995:3) bireylerin ve örgütlerin değerleri, ihtiyaçları ve ilgi alanları uyum gösterdiğinde daha verimli olduklarını ifade etmişlerdir.

Schneider vd. (1995:749) kişi-örgüt uyumunu "çalışanların sahip olduğu özellikler ile örgütün sahip olduğu özellikler arasında yaşanabilecek sorunların ortadan kaldırılması ve mümkün olduğunca ortak bir zeminde buluşulması" olarak ifade etmektedirler. Kişi-örgüt uyumu bireysel ve örgütsel değerlerin uyumudur. Bu doğrultuda kişi-örgüt uyumu genellikle "değer uyumluluğu" açısından tanımlanmaktadır (Kim vd., 2013:3719). Kristof (1996: 4-5)'a göre, kişi-örgüt uyumu, bir örgüt veya birey, birbirlerinin ihtiyaç duyduğu şeyleri sağladığı zaman meydana gelen, bireyler ve örgütler arasındaki uygunluk ya da bireylerin ve örgütlerin benzer temel özellikleri paylaşmasıdır. Kişi-örgüt uyumu, "örgütün değerleri, hedefleri ve misyonu ile kişinin ne derecede uyuştuğu ile ilgilidir" (Lauver ve Kristof-Brown, 2001:455).

\section{2. İşle Bütünleşme}

İşle bütünleşme ilk olarak Kahn tarafından örgüt üyelerinin özlerini, yani bireyin tüm duygu düşüncelerini şimdi ve burada olan iş rollerine bağlaması olarak tanımlanmıştır (Kahn, 1990:694). Maslach ve Leiter (2008) 
işle bütünleşmeyi tükenmişliğin olumlu karşıtı olarak görmüşlerdir. İşle bütünleşmeyi, dinç olma, adanmışlık ve içinde olma ile adlandırmışlar ve tükenmişliği işle bütünleşmenin kaybedilmesi olarak ifade etmişlerdir (Maslach ve Leiter, 2008: 12). Schaufeli ve Bakker (2004:293)'a göre işle bütünleşme olumlu yerine getirici, zindelik, adanmışlık ve yoğunlaşma ile nitelenen zihnin işle ilgili durumudur. Zindelik çalışırken yüksek seviyede enerjiye sahip olma, çaba sarf etme, zihinsel güçlülük ve esneklikle tarif edilir. Adanmışlık kişinin işine güçlü bir şekilde bağlllığıyla ifade edilir. Yoğunlaşma, kişinin işine tümüyle yoğunlaşmasıyla ve işinde mutlu olmasıyla ifade edilir.

Kahn işle bütünleşmeyi açıklarken kişisel bütünleşme ve kişisel ayrıklık kavramlarını kullanmıştır. Eğer işletme çalışanları kendi kimliklerini yaptıkları işe dâhil ediyorlarsa kişisel bütünleşme meydana gelir. Bu durumda çalışanlar, rollerini yerine getirirken kendilerini, fiziksel, zihinsel ve duygusal olarak ortaya koyarlar ve gösterirler. Kişisel ayrıklık durumu ise, kişinin kendisi ile oynadığı rolün eşleşmediği durumlarda ortaya çıkar ve bu durumda çalışanlar kendilerini fiziksel, zihinsel ve duygusal olarak geri çeker ve korurlar (Kahn, 1990: 694). Kişi işinde zamanın nasıl geçtiğini anlamıyorsa, işini zevkle yapıyorsa ve işini yaptığı esnada işinden başka hiçbir şey düşünmüyorsa ve yaptığı işte kendinden bir parça görüyorsa işiyle bütünleşmiş demektir. Bu durum işgören ve çalışılan örgüt açısından olumlu bir hava yaratacaktır (Ar1, 2011:36).

İşle bütünleşmede etkili olan faktörler, bireysel ve örgütsel faktörler olmak üzere iki grupta toplanmaktadır. Bireysel faktörler kapsamında kişide işle bütünleşmenin sağlanabilmesi için mesleği ile ilgili bilgi, yetenek, beceri birikimine sahip olması öncelikli olarak gereklidir. Bununla birlikte birey ihtiyaçlarının neler olduğunu bilmeli ve kariyer gelişimine önem vermelidir (Maslach ve Goldberg, 1998:69). Ayrıca çalışanların kişilik özellikleri işle bütünleşme düzeylerini de belirlemektedir. İşle bütünleşmiş kişiler genel olarak yaratıcı, hareketli, enerjik ve cana yakın, sorumluluk sahibi ve uyumlu kişilerdir (Polatçı vd., 2007:18).

Kişinin kendisi için anlamlı bir işe sahip olma isteği, çalışanın işiyle uyumunun yüksek olmasına, işgörenin işini yaparken kendini değerli ve önemli bulmasına bağlıdır (Atçığlu, 2018:54). Çalışanın iş yükünün sürdürülebilir olması, örgütte sağlıklı bir denetim ve ödül sisteminin olması, kişinin örgütüne olan aidiyetinde artma, adaletli yönetim, saygı ve değerlerin uyuşması kişinin işiyle olan uyumunu artırarak işle bütünleşme düzeyinin artmasında olumlu yönde etkiye sebep olmaktadır (Ertemli, 2011:73).

\subsection{Kişi-Örgüt Uyumunun İşle Bütünleşmeye Etkisine Yönelik Araştırmalar}

Kişi-örgüt uyumu örgüt başarısında ve çalışanların motivasyon ve başarımında rol oynayan önemli bir girdidir. Sortheix vd. (2013) gerçekleştirdikleri araştırmada kişi-örgüt uyumunun işle bütünleşme arasında güçlü bir ilişki olduğunu tespit etmişlerdir. Rahmadani ve Sebayang (2017) polis memurları ile gerçekleştirdikleri araştırmada kişi-örgüt uyumunun işle bütünleşmeye etkisini incelemişlerdir. Araştırma sonucunda bireysel özelliklerin örgütün özellikleriyle (kişi-örgüt uyumu) uygunluğunun işle bütünleşme düzeyini etkilediğini tespit etmişlerdir. Erkal (2019) 382 çalışan ile gerçekleştirdiği araştırmada kişi-örgüt uyumunun işle bütünleşmeyi pozitif ve anlamlı bir şekilde etkilediğini ortaya koymuştur. Božac, Sušanj ve Besim (2017) kişi-örgüt uyumu, işle bütünleşme, örgütte kalma niyeti ve örgütsel bağlılık arasındaki ilişkileri Hırvatistan'daki otel çalışanları üzerinde araştırmışlardır. Çalışma sonucunda söz konusu değişkenler arasında kuvvetli ilişkiler tespit edilmiş ve çalışanların işle bütünleşme düzeyinin büyük oranda kişi-örgüt uyumu tarafından yordandığını ortaya koymuşlardır.

Hamid ve Yahya (2011) Malezya'da 271 mühendis ile gerçekleştirdikleri araştırmada kişi-iş uyumu ve kişiörgüt uyumunun işle bütünleşmeyi pozitif yönde etkilediğini tespit etmişlerdir. Peng vd. (2014) 349 hemşire ile gerçekleştirdikleri araştırmada kişi-örgüt uyumu ile işle bütünleşme arasında güçlü bir korelasyon ilişkisi $(\mathrm{r}=0,59, \mathrm{p}<0,01)$ tespit etmişlerdir. Ayrıca araştırma sonucunda işle bütünleşmenin kişi-örgüt uyumunun işten ayrılma niyeti üzerinde kısmi aracılık etkisi olduğunu ortaya koymuşlardır. Benzer şekilde Memon vd. (2018) işle bütünleşmenin kişi-örgüt uyumunun işten ayrılma niyetinde aracılık etkisinin olduğunu tespit etmişlerdir. 


\section{ARAŞTIRMANIN METODOLOJÍSİ}

\subsection{Araştırmanın Amacı, Modeli Ve Hipotezleri}

Araştırmanın amacı kişi-örgüt uyumunun işle bütünleşme üzerindeki etkisinin ve çalışanların kişi-örgüt uyumu ile işle bütünleşme düzeylerinin bazı değişkenlere göre farklılaşıp farklılaşmadığının incelenmesidir. Araştırma ilişkisel tarama modeli kullanılarak gerçekleştirilmiştir. Araştırmanın amacı ve literatür taraması doğrultusunda araştırmanın hipotezleri aşağıdaki şekilde oluşturulmuştur;

H1; Kişi-örgüt uyumunun işle bütünleşmenin zindelik boyutu üzerinde pozitif yönlü ve anlamlı etkisi vardır.

H2; Kişi-örgüt uyumunun işle bütünleşmenin adanma boyutu üzerinde pozitif yönlü ve anlamlı etkisi vardır.

H3; Kişi-örgüt uyumunun işle bütünleşmenin yoğunlaşma boyutu üzerinde pozitif yönlü ve anlamlı etkisi vardır.

H4; Kişi-örgüt uyumu cinsiyete göre anlamlı farkl1lık göstermektedir.

H5; İşle bütünleşme düzeyi (H5a;zindelik, H5b; adanma, H5c; yoğunlaşma) cinsiyete göre anlamlı farklılık göstermektedir.

H6; Kişi-örgüt uyumu medeni duruma göre anlamlı farklılık göstermektedir.

H7; İşle bütünleşme düzeyi (H7a;zindelik, H7b; adanma, H7c; yoğunlaşma) medeni duruma göre anlamlı farklılık göstermektedir.

H8; Kişi-örgüt uyumu eğitim durumuna göre anlamlı farklılık göstermektedir.

H9; İşle bütünleşme düzeyi (H9a;zindelik, H9b; adanma, H9c; yoğunlaşma) eğitim durumuna göre anlamlı farklılık göstermektedir.

H10; Kişi-örgüt uyumu çalışma süresine göre anlamlı farklılık göstermektedir.

H11; İşle bütünleşme düzeyi (H11a;zindelik, H11b; adanma, H11c; yoğunlaşma) çalışma süresine göre anlamlı farklılık göstermektedir.

\subsection{Kattlimcilar}

Araştırmanın evrenini, Ankara ili merkez ilçede hizmet sektörü çalışanları oluşturmaktadır. Verilerin toplanması amacıyla anket yöntemi ve tüm evrene ulaşılmasında ki güçlüklerden kaynaklı örnekleme yöntemi kullanılmıştır. Kolayda örnekleme yöntemi kullanılarak 2019 yılı Temmuz-Kasım ayları arasında gönüllü katılım esasıyla 411 hizmet sektörü çalışanından yüz yüze görüşme yöntemi ile anket verileri toplanmıştır. Araştırmanın evrenini oluşturan hizmet sektörü çalışanı sayısı tam olarak bilinmemekle beraber \%5 anlamlılık seviyesinde 384 örneklem sayısının evreni temsil etme sınırları içerisindedir (Krejcie ve Morgan, 1970;608). Buna göre 411 çalışandan oluşan örneklemin, çalışma evreninin temsil gücünün yeterli olduğu söylenebilir.

Araştırmanın örnekleminin \% 63,7'si (n=262) erkek ve \%36,3 'ü (n=149) kadın çalışanlardan oluşmaktadır. Çalışanların \% 68,4'ü (n=281) evli, \%31,6'sı ( $\mathrm{n}=130)$ bekârdır, \% 37,2'si ( $\mathrm{n}=153)$ çocuk sahibi değilken, \% 7,3'ünün (n=30) 1 çocuğu, \% 38'inin (n=156) 2 çocuğu, \% 15,1'inin (n=62) 3 çocuğu ve \% 2,4'ünün (n=10) 4 çocuğu vardır. Çalışmaya katılanların \% 12,9'u (n=53) 26 yaş altında, \% 24,6'sı $(n=101) 26$ yaş ve 35 yaş arasında, \% 28'i (n=115) 35 yaş ve 45 yaş aralığında, \% 34,5'i (n=142) 45 yaş ve üzerindedir. Katılımcıların \% 20,9'u ( $n=86)$ ilköğretim-ortaöğretim mezunu, \% 45'i ( $n=185)$ lise mezunu, \% 14,4'ü (n=59) önlisans mezunu, $\%$ 19,7'si (n=81) lisans mezunudur. Örneklemin \% 22,1'i (n=91) 5 yıl ve daha az süredir, \% 22,6's1 (n=93) 6 yıl ve 10 yıl arası, \% 26'sı (n=107) 11-20 yıl arası, \% 29,2'si $(\mathrm{n}=120) 21$ yıl ve daha uzun süredir çalışmaktadır. Katılımciların \% 5,8'i (n=24) 1 yıl ve daha az süredir, \% 36'sı (n=148) 2 yıl ve 6 yıl arası, \% 27,5'i (n=113) 6 yıl ve 10 yıl arası, \% 30,7'si (n=126) 10 yıl ve daha fazla süredir mevcut işyerinde çalışmaktadır. 


\subsection{Veri Toplama Araçları}

Araştırmada veri toplamak amacıyla kantitatif yöntemlerden anket tekniği kullanılmıştır. Araştırmada kullanılan anket üç bölüm, 7 soru ve 20 maddeden oluşmaktadır. Birinci bölüm "kişisel bilgi formu" başlığ1 altında katılımcıların araştırmanın amacına yönelik değişkenlerle ilgili olduğu düşünülen kişisel özelliklerle ilgili 7 sorudan oluşmaktadır ve araştırmacı tarafından geliştirilmiştir. Bu bölümde katılımcılara ait cinsiyet, medeni durum, çocuk sayısı, yaş, eğitim durumu, toplam çalışma süresi ve mevcut işyerinde çalışma süresi değişken olarak belirlenmiştir. Anketin ikinci bölümünü katılımcıların kişi-örgüt uyumu düzeylerini ölçmeye yönelik "Kişi-Örgüt Uyumu Ölçeği", üçüncü bölümünü katılımcıların işle bütünleşme düzeylerini ölçmeye yönelik "İşle Bütünleşme Ölçeği" oluşturmaktadır. Ölçekler 5'li likert tarzında (1= Kesinlikle Katılmıyorum, 5= Kesinlikle Katılıyorum) derecelendirilmiştir.

Kişi-Örgüt Uyumu Ölçeği: Katılımcıların kişi-örgüt uyumu düzeyini belirlemek üzere Netemeyer vd. (1997) tarafından geliştirilen, 4 ifade ve tek boyuttan oluşan Kişi-Örgüt Uyumu Ölçeği kullanılmıştır. Bu ölçekte sorular, "çalıştı̆̆ım kurumun değerleri ile kişisel değerlerimin uyumlu olduğunu düşünüyorum" şeklindedir. Ölçek Türkiye' de pek çok araştırmada (Özdemir vd., 2017; Turunç ve Çelik, 2012; Pekdemir vd., 2013; Polatçı ve Cindiloğlu, 2013; Türe Yılmaz vd., 2019; Özgen ve Turunç, 2017) kullanılmış, geçerliliği ve güvenilirliği tespit edilmiştir.

İşle Bütünleşme Ölçeği; Araştırmada katılımcıların işle bütünleşme seviyelerini belirlemek için Ultrecht İşle Bütünleşme Ölçeği (Schaufeli vd., 2002) kullanılmıştır. Ölçek 17 madde ve üç alt boyuttan (zindelik, adanma, yoğunlaşma) oluşmaktadır. Ölçekte yer alan zindelik (vigor), yüksek düzeyde direnç ve zorluklar karşısında bile çalışmaya istekli olunması ile adanma (dedication), çalışanın işini tutku ile yapması ile yoğunlaşma (absorption) ise çalışanın işine tamamıyla ve zaman kavramı olmaksızın odaklanması ile ifade edilmektedir. Ölçekte sorular, "işimde çok fazla çaba gösteririm", "işimle ilgili heyecanlıyım", " işimle gurur duyuyorum" şeklindedir. Ölçek Türkiye'de pek çok araştırmada (Vatansever Durmaz, 2019; Turgut, 2011; Eryılmaz ve Doğan, 2012; Gündüz vd. 2013; Baş Atik 2018; Gün, 2017 ) kullanılmış, geçerliliği ve güvenilirliği tespit edilmiştir.

\subsection{Verilerin Analizi}

Araştırmada elde edilen veriler SPSS ve AMOS programları kullanılarak analiz edilmiştir. Tanımlayıcı istatistiksel yöntemler kapsamında veriler sayı, yüzde, ortalama ve standart sapma kullanılarak değerlendirilmiştir. Ölçeklerin yapı geçerliliği ve güvenilirliliği doğrulayıcı faktör analizi (DFA), yakınsak geçerliliği (AVE), birleşim güvenilirliği (CR) ve Cronbach alfa kat sayıları hesaplanarak sınanmıştır. Hipotezlerin test edilmesinden önce verilerin normal dağılım durumu sınanmıştır. Verilerin basıklık ve çarpıklık değerlerinin -1 ile +1 arasında olduğu ve verilerin normal dağılım gösterdiği tespit edilmiştir (George ve Mallery, 2001). Hipotezlerin test edilmesinde yapısal eşitlik modellemesinde yol analizi kullanılmıştır. Fark analizlerinde iki bağımsız grup arasında karşılaştırmalarda t-testi, ikiden fazla bağımsız grup arasında karşılaştırmalarda tek faktörlü varyans analizi testi kullanılmıştır. Tek faktörlü varyans analizi sonrasında farklılıkları belirlemek üzere post-hoc analizlerinden Tukey testi kullanılmıştır.

DFA ve yol analizlerinde uyum, ki kare uyum testi ( $\left.x^{2} / \mathrm{sd}\right)$, uyum iyiliği indeksi (GFI), karşılaştırmalı uyum indeksi (CFI), Tucker-Lewis indeksi (TLI) ve yaklaşık hataların ortalama karekökü (RMSEA) aracilığıyla incelenmiştir. Söz konusu değerlerde uyumdan bahsedebilmek için değerler şu şekilde olmalıdır; $x^{2} / s d$ değeri 5'e eşit veya küçük olmalı, GFI değeri 0,85'e eşit veya büyük olmalı, RMSEA değeri 0,08'e eşit veya küçük olmalı, TLI ve CFI değerleri ise 0,90'a eşit veya büyük olmalıdır (Bentler, 1990; Kline, 1998; Schermelleh-Engel vd., 2003; Bryne ve Campell, 1999).

Yakınsak geçerlilikten bahsedebilmek için AVE değerinin 0,50'nin üzerinde, bileşik güvenilirlik değerinin (CR) de 0,70'in üzerinde olması gerekmektedir (Fornell ve Larcker, 1981). Ölçeğin güvenilir olması için Cronbach alfa değerinin 0,70'nin üzerinde olması gerekmektedir (Altunışık vd., 2010: 124). 


\section{BULGULAR}

\subsection{Geçerlilik Ve Güvenilirlik Analizleri}

Ölçeklerin yapı geçerliliğinin test edilmesi amacıyla öncelikle DFA gerçekleştirilmiştir. Kişi-Örgüt uyumu ölçeğinin tek faktörlü yapısı DFA analizi ile doğrulanmıştır. Modele ilişkin uyum iyiliği indeks değerleri Tablo 1'de sunulmuştur.

Tablo 1. Kişi-Örgüt Uyumu Ölçeği DFA Sonuçları

\begin{tabular}{|c|c|c|c|c|c|c|c|c|c|}
\hline \multirow[t]{2}{*}{ Değişken } & \multirow[t]{2}{*}{ Maddeler } & \multirow{2}{*}{$\begin{array}{c}\text { Faktör } \\
\text { Yükü }\end{array}$} & \multirow{2}{*}{$\begin{array}{c}\text { Standart } \\
\text { Hata }\end{array}$} & \multirow{2}{*}{$\begin{array}{c}t- \\
\text { değeri }\end{array}$} & \multicolumn{5}{|c|}{ Uyum İyiliği Değerleri } \\
\hline & & & & & $\mathbf{X}^{2} / \mathbf{s d}$ & GFI & CFI & TLI & RMSEA \\
\hline \multirow{4}{*}{$\begin{array}{l}\text { Kişi-Örgüt } \\
\text { Uyumu }\end{array}$} & KÖU1 & 0,648 & - & - & \multirow{4}{*}{2,237} & \multirow{4}{*}{0,997} & \multirow{4}{*}{0,998} & \multirow{4}{*}{0,988} & \multirow{4}{*}{0,055} \\
\hline & KÖU2 & 0,775 & 0,079 & 13,723 & & & & & \\
\hline & KÖU3 & 0,958 & 0,104 & 12,952 & & & & & \\
\hline & KÖU4 & 0,521 & 0,079 & 8,133 & & & & & \\
\hline
\end{tabular}

Kişi-örgüt uyumu ölçeğinin DFA'ne ilişkin uyum iyiliği değerleri kabul edilebilir sınırlar içerisindedir ve ölçeğin iyi uyum gösterdiği kabul edilmektedir (Tablo 1).

İşle bütünleşme ölçeğinin birinci düzey (Model 1), ikinci düzey (Model 2) ve tek faktör yapısına (Model 3) yönelik gerçekleştirilen DFA sonuçları ve uyum iyiliği değerleri Tablo 2'de gösterilmiştir.

Tablo 2. İşle Bütünleşme Ölçeği DFA Sonuçları

\begin{tabular}{|c|c|c|c|c|c|c|}
\hline \multirow[t]{2}{*}{ Değişken } & \multirow[t]{2}{*}{ Model } & \multicolumn{5}{|c|}{ Uyum İyiliği Değerleri } \\
\hline & & $X^{2} / s d$ & GFI & CFI & RMSEA & TLI \\
\hline \multirow{3}{*}{ İşle Bütünleşme } & Model 1 & 4,555 & 0,878 & 0,937 & 0,093 & 0,921 \\
\hline & Model 2 & 5,539 & 0,851 & 0,916 & 0,105 & 0,899 \\
\hline & Model 3 & 20,787 & 0,508 & 0,604 & 0,220 & 0,558 \\
\hline
\end{tabular}

Tablo 2 incelendiğinde işle bütünleşme ölçeğinin DFA sonuçları incelendiğinde en iyi uyumu gösteren model birinci düzey DFA (Model 1) sonuçlarıdır. Model 1'in sonuçları üzerinden önerilen modifikasyon indeksleri uygulanarak elde edilen sonuçlar Tablo 3'de sunulmuştur.

Tablo 3. İşle Bütünleşme Ölçeği Model 1 DFA Sonuçları

\begin{tabular}{|c|c|c|c|c|c|c|c|c|c|}
\hline \multirow{2}{*}{ Değişken } & \multirow[t]{2}{*}{ Maddeler } & \multirow{2}{*}{$\begin{array}{c}\text { Faktör } \\
\text { Yüküu }\end{array}$} & \multirow{2}{*}{$\begin{array}{c}\text { Standart } \\
\text { Hata }\end{array}$} & \multirow[t]{2}{*}{ t-değeri } & \multicolumn{5}{|c|}{ Uyum İyiliği Değerleri } \\
\hline & & & & & $\mathrm{X}^{2} / \mathrm{sd}$ & GFI & CFI & RMSEA & TLI \\
\hline \multirow{6}{*}{$\begin{array}{l}\text { İşle } \\
\text { Bütünleşme } \\
\text { (Zindelik) }\end{array}$} & ZIN1 & 0,744 & 0,055 & 16,415 & \multirow{17}{*}{4,194} & \multirow{17}{*}{0,896} & \multirow{17}{*}{0,948} & \multirow{17}{*}{0,088} & \multirow{17}{*}{0,929} \\
\hline & ZiN2 & 0,859 & 0,057 & 17,612 & & & & & \\
\hline & ZiN3 & 0,846 & 0,055 & 17,457 & & & & & \\
\hline & ZiN4 & 0,835 & 0,054 & 18,393 & & & & & \\
\hline & ZiN5 & 0,876 & 0,051 & 19,082 & & & & & \\
\hline & ZiN6 & 0,843 & - & - & & & & & \\
\hline \multirow{5}{*}{$\begin{array}{l}\text { İşle } \\
\text { Bütünleşme } \\
\text { (Adanma) }\end{array}$} & AD1 & 0,819 & 0,057 & 19,060 & & & & & \\
\hline & AD2 & 0,890 & 0,054 & 21,455 & & & & & \\
\hline & AD3 & 0,870 & 0,055 & 20,801 & & & & & \\
\hline & AD4 & 0,927 & 0,051 & 22,774 & & & & & \\
\hline & AD5 & 0,799 & - & - & & & & & \\
\hline \multirow{6}{*}{$\begin{array}{l}\text { İşle } \\
\text { Bütünleşme } \\
\text { (Yoğunlaşma) }\end{array}$} & YOĞ1 & 0,809 & 0,053 & 18,152 & & & & & \\
\hline & YOĞ2 & 0,758 & 0,061 & 16,644 & & & & & \\
\hline & YOĞ3 & 0,853 & 0,056 & 19,453 & & & & & \\
\hline & YOĞ4 & 0,887 & 0,053 & 20,499 & & & & & \\
\hline & YOĞ5 & 0,869 & 0,056 & 19,953 & & & & & \\
\hline & YOĞ6 & 0,787 & - & - & & & & & \\
\hline
\end{tabular}


İşle bütünleşme ölçeği birinci düzey DFA (Model 1) modifikasyon indeksleri önerileri doğrultusunda hata terimleri arasında kovaryanslar çizilmesiyle iyi uyum değerlerine ulaşmıştır. Bu durumda işle bütünleşme ölçeğinin çalışmada birinci düzey faktör yapısı kabul edilmektedir.

Ölçeklerin DFA ile doğrulanan yapı geçerliliğine ek olarak yakınsaklık geçerliliği (AVE), birleşik güvenilirlik (CR) değerleri ve Cronbach alfa değerleri hesaplanmış ve sonuçlar Tablo 4'de sunulmuştur.

Tablo 4. Ölçeklerin AVE, CR ve Cronbach Alfa Değerleri

\begin{tabular}{|l|l|l|l|}
\hline Ölçek & AVE & CR & Cronbach alfa \\
\hline Kişi-örgüt uyumu & 0,552 & 0,824 & 0,804 \\
\hline İşle bütünleşme (genel) & 0,706 & 0,976 & 0,931 \\
\hline Zindelik & 0,697 & 0,932 & 0,927 \\
\hline Adanma & 0,743 & 0,935 & 0,935 \\
\hline Yoğunlaşma & 0,686 & 0,929 & 0,931 \\
\hline
\end{tabular}

Tablo 4 incelendiğinde tüm ölçeklerin AVE değerlerinin 0,50'nin üzerinde, CR değerlerinin 0,70'in üzerinde olduğu görülmektedir. Bu durumda ölçeklerin tümü yakınsak geçerlilik ve birleşik güvenilirlik şartlarını gerçekleştirmektedir. Cronbach alfa istatistikleri incelendiğinde ölçeklerin tümünün oldukça güvenilir olduğu görülmektedir. Sonuç olarak tüm geçerlilik ve güvenilirlik analiz sonuçları bütün olarak değerlendirildiğinde ölçeklerin geçerlilik şartlarını taşıdığı ve güvenilirliklerinin yüksek olduğu görülmektedir.

\subsection{Hipotez Testleri}

Öncelikle katılımcıların algıladıkları kişi-örgüt uyumu ve işle bütünleşmeye ilişkin elde edilen verilerin ortalamaları, standart sapmaları ve aralarındaki korelasyonlara bakılmış ve sonuçlar Tablo 5'de sunulmuştur.

Tablo 5. Korelasyon Analizi Sonuçları

\begin{tabular}{|l|l|l|l|l|l|l|}
\hline Değişken & Ortalama & Standart Sapma & 1 & 2 & 3 & 4 \\
\hline Kişi-örgüt uyumu (1) & 3,2597 & 0,81874 & 1 & & & \\
\hline Zindelik (2) & 3,5718 & 0,90470 & $0,563^{* *}$ & 1 & & \\
\hline Adanma (3) & 4,0526 & 0,86783 & $0,271^{* *}$ & $0,439^{* *}$ & 1 & \\
\hline Yoğunlaşma (4) & 3,9651 & 0,88330 & $0,149^{* *}$ & $0,312^{* *}$ & $0,621^{* *}$ & 1 \\
\hline "p<0.01
\end{tabular}

Korelasyon analizi sonucu değişkenler arasında 0,01 anlamlılık düzeyinde aynı yönde ilişki olduğu tespit edilmiştir. Ölçeklerin ortalama değerleri incelendiğinde genel olarak çalışanların kişi-örgüt uyumu düzeyleri orta seviyede, işle bütünleşme düzeylerinin ise yüksek olduğu görülmektedir (Tablo 5 ).

Araştırmanın kapsamında kişi-örgüt uyumunun işle bütünleşmenin boyutları (zindelik, adanma ve yoğunlaşma) üzerindeki etkileri araştırılmaktadır. Bu kapsamda gerçekleştirilen yol analizine ilişkin uyum iyiliği değerleri kabul edilebilir sınırlar içerisindedir $\left(X^{2} / \mathrm{sd}=4,140 ; \mathrm{GFI}=0,863\right.$; CFI=0,906; RMSEA=0,088; TLI= 0,906). Şekil 1'de yol analizine ilişkin bulgular gösterilmektedir.

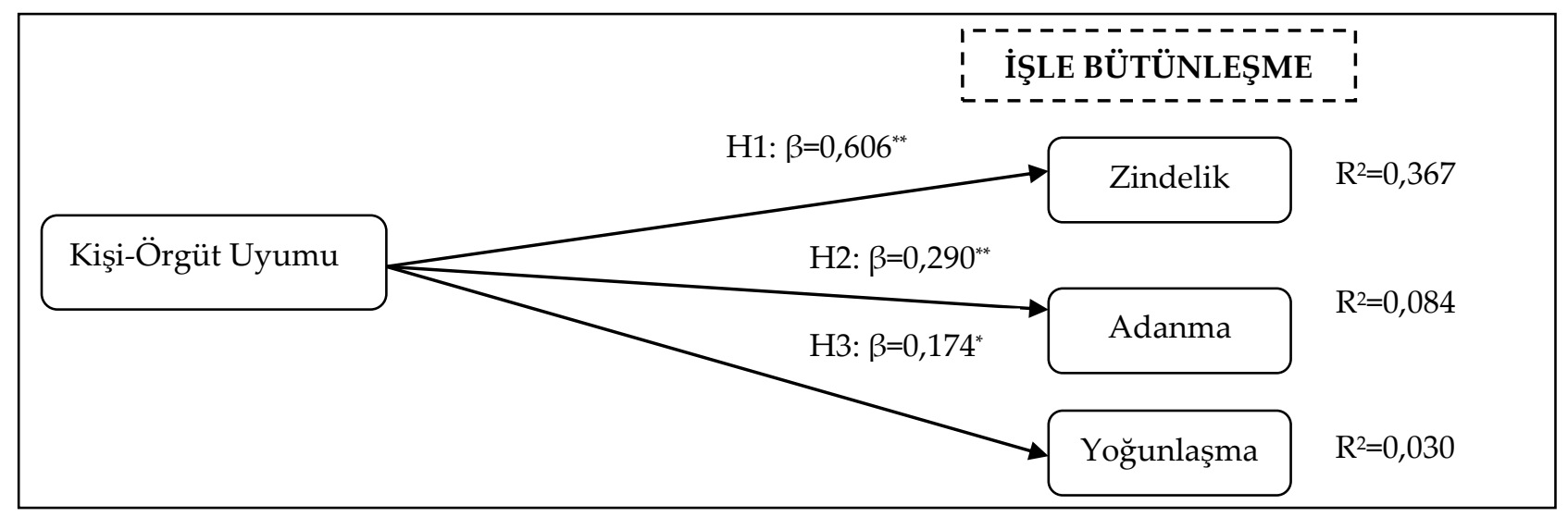

"p<0.05, " $\mathrm{p}<0.01$

Şekil 1. Kişi-Örgüt Uyumunun İşle Bütünleşme Üzerindeki Etkisi 
Şekil 1'deki sonuçlar incelendiğinde kişi-örgüt uyumunun işle bütünleşmenin zindelik $(\beta=0,606, p<0,01)$, adanma $(\beta=0,290, p<0,01)$ ve yoğunlaşma $(\beta=0,174, p<0,05)$ boyutları üzerinde pozitif yönde ve anlamlı etkisi olduğu tespit edilmiştir. Bu bulguya göre $\mathrm{H1}, \mathrm{H} 2$ ve $\mathrm{H} 3$ hipotezleri kabul edilmektedir.

Çalışanların kişi-örgüt uyumu ile işle bütünleşme düzeylerinin (zindelik, adanma ve yoğunlaşma) cinsiyet ve medeni durumlarına göre anlamlı farklılık gösterip göstermediğini test edebilmek için Bağımsız Örneklemlerde T-Testi yapılmıştır. Analiz sonuçları Tablo 6'da sunulmuştur.

Tablo 6. Bağımsız Örneklemlerde T-Testi Sonuçları

\begin{tabular}{|c|c|c|c|c|c|c|c|c|}
\hline \multicolumn{3}{|c|}{ Değişkenler } & $\mathbf{n}$ & Ort. & s.s. & s.d. & $\mathbf{t}$ & $\mathrm{p}$ \\
\hline \multirow{2}{*}{ Kişi-örgüt uyumu } & \multirow{8}{*}{ 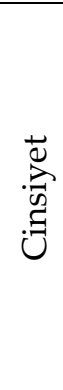 } & Kadın & 149 & 3,4866 & 0,84519 & \multirow{8}{*}{409} & $-4,226$ & 0,000 \\
\hline & & Erkek & 262 & 3,1307 & 0,77580 & & & \\
\hline \multirow[t]{2}{*}{ Zindelik } & & Kadın & 149 & 3,6600 & 0,84693 & & $-1,533$ & 0,136 \\
\hline & & Erkek & 262 & 3,5216 & 0,93383 & & & \\
\hline \multirow[t]{2}{*}{ Adanma } & & Kadın & 149 & 4,1691 & 0,85574 & & $-2,071$ & 0,039 \\
\hline & & Erkek & 262 & 3,9863 & 0,86929 & & & \\
\hline \multirow[t]{2}{*}{ Yoğunlaşma } & & Kadın & 149 & 4,0078 & 0,92661 & & $-0,723$ & 0,470 \\
\hline & & Erkek & 262 & 3,9408 & 0,85856 & & & \\
\hline \multirow[t]{2}{*}{ Kişi-örgüt uyumu } & \multirow{8}{*}{ 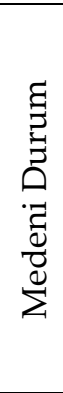 } & Evli & 281 & 3,2011 & 0,81726 & \multirow{8}{*}{409} & $-2,151$ & 0,032 \\
\hline & & Bekar & 130 & 3,3865 & 0,81061 & & & \\
\hline \multirow[t]{2}{*}{ Zindelik } & & Evli & 281 & 3,5558 & 0,91355 & & $-0,533$ & 0,594 \\
\hline & & Bekar & 130 & 3,6064 & 0,88776 & & & \\
\hline \multirow[t]{2}{*}{ Adanma } & & Evli & 281 & 4,0441 & 0,93200 & & $-0,318$ & 0,750 \\
\hline & & Bekar & 130 & 4,0708 & 0,71262 & & & \\
\hline \multirow[t]{2}{*}{ Yoğunlaşma } & & Evli & 281 & 3,8476 & 0,92550 & & $-4,414$ & 0,000 \\
\hline & & Bekar & 130 & 4,2192 & 0,72486 & & & \\
\hline
\end{tabular}

Tablo 6'da yer alan sonuçlar incelendiğinde kadın çalışanların kişi-örgüt uyum düzeyleri (ort.=3,47) erkek çalışanlara (ort. $=3,12$ ) oranla daha yüksektir ve fark istatistiki olarak anlamlıdır $(t=-4,226 ; p<0,01)$. Kadın çalışanların adanma düzeyleri (ort. $=4,16)$ erkek çalışanlara oranla $(3,98)$ daha yüksektir ve fark istatistiki olarak anlamlıdır $(t=-2,071 ; p<0,05)$. Bekar çalışanların kişi-örgüt uyumu ortalamaları $(o r t .=3,38)$ evli çalışanların kişi-örgüt uyumu ortalamalarından (ort.=3,20) yüksektir. Bekar çalışanların işe yoğunlaşma düzeyleri (ort.=4,21) evli çalışanların işe yoğunlaşma düzeylerinden (ort.= 3,84 ) daha yüksektir ve fark istatistiki olarak anlamlıdır $(t=-4,414 ; \mathrm{p}<0,01)$. Diğer değişkenler arasında anlamlı bir farklılık tespit edilmemiştir. Bu bulgular doğrultusunda H4, H5b, H6 ve H7c hipotezleri kabul edilmekte, H5a, , H5c, H7a ve $\mathrm{H7b}$ hipotezleri red edilmektedir.

Çalışanların kişi-örgüt uyumu ile işle bütünleşme düzeylerinin (zindelik, adanma ve yoğunlaşma) eğitim durumlarına göre anlamlı farklılık gösterip göstermediğini test edebilmek için tek faktörlü varyans analizi yapılmıştır. Analiz sonuçları Tablo 7'de sunulmuştur.

Tablo 7. Eğitim Durumlarına Göre Tek Faktörlü Varyans Analizi Sonuçları

\begin{tabular}{|c|c|c|c|c|c|c|}
\hline Değişken & Eğitim Durumu & $\mathbf{n}$ & Ort. & s.s. & $\mathbf{F}$ & $\mathbf{p}$ \\
\hline \multirow{4}{*}{ Kişi-Örgüt Uyumu } & Lise altı & 86 & 3,3692 & 0,90645 & \multirow{4}{*}{15,480} & \multirow{4}{*}{0,000} \\
\hline & Lise & 185 & 3,1419 & 0,66129 & & \\
\hline & Önlisans & 59 & 2,8686 & 0,94954 & & \\
\hline & Lisans & 81 & 3,6975 & 0,74237 & & \\
\hline \multirow[t]{4}{*}{ Zindelik } & Lise alt1 & 86 & 3,6880 & 0,92135 & \multirow{4}{*}{7,215} & \multirow{4}{*}{0,000} \\
\hline & Lise & 185 & 3,4162 & 0,86220 & & \\
\hline & Önlisans & 59 & 3,4124 & 1,08647 & & \\
\hline & Lisans & 81 & 3,9198 & 0,71788 & & \\
\hline \multirow[t]{3}{*}{ Adanma } & Lise alt1 & 86 & 4,1884 & 0,83925 & \multirow[b]{3}{*}{12,249} & \multirow[b]{3}{*}{0,000} \\
\hline & Lise & 185 & 3,8627 & 0,92687 & & \\
\hline & Önlisans & 59 & 3,8576 & 0,82550 & & \\
\hline
\end{tabular}




\begin{tabular}{|l|l|l|l|l|l|l|}
\hline & Lisans & 81 & 4,4840 & 0,56733 & & \\
\hline \multirow{3}{*}{ Yoğunlaşma } & Lise altı & 86 & 4,1298 & 0,90076 & & \\
\cline { 2 - 5 } & Lise & 185 & 3,8387 & 0,91037 & \multirow{3}{*}{3,637} & \multirow{2}{*}{0,013} \\
\cline { 2 - 5 } & Önlisans & 59 & 3,8757 & 0,92205 & \\
\cline { 2 - 5 } & Lisans & 81 & 4,1440 & 0,71383 & & \\
\hline
\end{tabular}

Tablo 7 incelendiğinde çalışanların eğitim durumlarına göre kişi-örgüt uyumu düzeyleri $(\mathrm{F}=5,766 ; \mathrm{p}<0,05)$, zindelik $(\mathrm{F}=2,976 ; \mathrm{p}<0,05)$, adanma $(\mathrm{F}=4,341 ; \mathrm{p}<0,05)$ ve yoğunlaşma düzeyleri $(\mathrm{F}=1,260 ; \mathrm{p}<0,05)$ istatistiki olarak anlamlı farklılık göstermektedir. Farklılıkların hangi ikili gruptan (gruplardan) kaynaklandığını gösteren çoklu karşılaştırma Tukey testi sonuçlarına bakıldığında lisans mezunu çalışanlar (ort. $=3,69)$ ile lisealtı (ort.=3,36), lise (ort.=3,14) ve önlisans (ort. $=2,86$ ) mezunu çalışanların ve lise altı (ort. $=3,36$ ) ve önlisans (ort.=2,86) mezunu çalışanların kişi-örgüt uyumu düzeyleri arasında anlamlı bir farklılık olduğu görülmüştür. Lisans mezunu (ort.=3,91) çalışanların zindelik düzeyleri lise (ort.=3,41) ve önlisans mezunu (ort.=3,41) çalışanların zindelik düzeylerinden yüksektir ve farklılık istatistiki olarak anlamlıdır. Aynı şekilde lisans mezunu (ort. $=4,48$ ) çalışanların adanma düzeyi ortalamaları ile lise (ort.=3,86) ve önlisans mezunu (ort. $=3,85$ ) çalışanların adanma düzeyi ortalamaları arasındaki fark istatistiki olarak anlamlıdır. Lise mezunu (ort. $=3,41)$ çalışanların adanma düzeyleri lise altı mezunu (ort. $=4,18)$ çalışanların adanma düzeylerinden daha düşüktür ve farklılık istatistiki olarak anlamlıdır. Lisans mezunu (ort. $=4,14)$ çalışanlar ile lise mezunu (ort.=3,83) çalışanların yoğunlaşma düzeyleri arasında istatistiki olarak anlamlı farklılık bulgulanmıştır. Bu sonuçlara göre $\mathrm{H} 8, \mathrm{H} 9 \mathrm{a}, \mathrm{H} 9 \mathrm{~b}$ ve H9c hipotezleri kabul edilmektedir.

Çalışanların kişi-örgüt uyumu ile işle bütünleşme düzeylerinin (zindelik, adanma ve yoğunlaşma) mevcut işyerinde çalışma sürelerine göre anlamlı farklılık gösterip göstermediğini test edebilmek için tek faktörlü varyans analizi yapılmış ve sonuçlar Tablo 8'de sunulmuştur.

Tablo 8. Çalışma Süresine Göre Tek Faktörlü Varyans Analizi Sonuçları

\begin{tabular}{|c|c|c|c|c|c|c|}
\hline Değişken & Çalışma Süresi & $\mathbf{n}$ & Ort. & s.s. & F & $\mathrm{p}$ \\
\hline \multirow{4}{*}{ Kişi-Örgüt Uyumu } & 1 yil ve daha az & 24 & 3,5625 & 0,77407 & \multirow{4}{*}{2,389} & \multirow{4}{*}{0,068} \\
\hline & $2-6$ yıl arası & 148 & 3,3412 & 0,75826 & & \\
\hline & 6 y1l ve 10 yıl arası & 113 & 3,1858 & 0,77473 & & \\
\hline & 10 yıl ve daha fazla & 126 & 3,1726 & 0,91458 & & \\
\hline \multirow[t]{4}{*}{ Zindelik } & 1 yil ve daha az & 24 & 3,3403 & 1,21433 & \multirow{4}{*}{1,088} & \multirow{4}{*}{0,354} \\
\hline & 2-6 yıl arası & 148 & 3,6565 & 0,78155 & & \\
\hline & 6 y1l ve 10 yıl arası & 113 & 3,5192 & 0,81855 & & \\
\hline & 10 yil ve daha fazla & 126 & 3,5635 & 1,03599 & & \\
\hline \multirow[t]{4}{*}{ Adanma } & 1 yil ve daha az & 24 & 3,4250 & 0,90853 & \multirow{4}{*}{10,891} & \multirow{4}{*}{0,000} \\
\hline & 2-6 y1l arası & 148 & 4,1405 & 0,69339 & & \\
\hline & 6 yıl ve 10 yıl arası & 113 & 3,8212 & 1,03142 & & \\
\hline & 10 yıl ve daha fazla & 126 & 4,2762 & 0,78500 & & \\
\hline \multirow[t]{4}{*}{ Yoğunlaşma } & 1 y1l ve daha az & 24 & 3,7014 & 0,64076 & \multirow{4}{*}{4,666} & \multirow{4}{*}{0,003} \\
\hline & 2-6 yıl arası & 148 & 4,1104 & 0,80872 & & \\
\hline & 6 yıl ve 10 yıl arası & 113 & 3,7507 & 1,00498 & & \\
\hline & 10 yil ve daha fazla & 126 & 4,0370 & 0,85111 & & \\
\hline
\end{tabular}

Tablo 8 incelendiğinde çalışanların işyerinde çalışma sürelerine göre adanma düzeyleri $(\mathrm{F}=10,891 ; \mathrm{p}<0,01)$ ve yoğunlaşma düzeyleri $(\mathrm{F}=4,666 ; \mathrm{p}<0,05)$ istatistiki olarak anlamlı farklılık göstermektedir. Farklılıkların hangi ikili gruptan (gruplardan) kaynaklandığını gösteren çoklu karşılaştırma Tukey testi sonuçlarına bakıldığında 10 yıl ve daha fazla süredir çalışanlar (ort.=4,27) ile 1 yıl ve daha az çalışanlar (ort.=3,42) ile 6-10 yıl arası çalışanların (ort.=3,82) adanma düzeyleri arasında anlamlı bir farklılık olduğu görülmüştür. Ayrıca 1 yıl ve daha az çalışanların (ort.=3,42) adanma düzeyleri 2 ve 6 yıl arası çalışanların (ort. $=4,14$ ) adanma düzeylerinden daha düşüktür ve farklılık istatistiki olarak anlamlıdır. 2 ve 6 yıldır çalışanların (ort.=4,14) adanma düzeyleri 6 yıl ve 10 yıl arası süredir (ort.=3,82) çalışanların adanma düzeylerinden daha yüksektir. Benzer şekilde 2 ve 6 yıldır çalışanların (ort.=4,11) yoğunlaşma düzeyleri 6 yıl ve 10 yıl arası çalışanların (ort.=3,75) yoğunlaşma düzeylerinden daha yüksektir ve farklılık istatistiki olarak anlamlıdır. Çalışanların 
çalışma sürelerine göre kişi-örgüt uyumu düzeyleri $(F=2,389 ; p>0,05)$ ve zindelik $(F=1,088 ; p>0,05)$ düzeyleri istatistiki olarak anlamlı farklılık göstermemektedir Bu sonuçlara göre H11b ve H11c hipotezleri kabul edilmekte ve $\mathrm{H} 10$ ve H11a hipotezleri red edilmektedir.

\section{SONUÇ VE TARTIŞMA}

Araştırmada çalışanların işle bütünleşme düzeylerinin kişi-örgüt uyumu aracılığı ile artacağı ve çalışanların kişi-örgüt uyumu algıları ile işle bütünleşme düzeylerinin demografik değişkenlere göre farklılaşacağı ortaya konmaya çalışılmaktadır. İşle bütünleşme kişinin istekle ve tüm enerjisini yönlendirerek işini yapmasıdır. İşiyle bütünleşmiş çalışanlar enerjilerini işlerine yansıtırlar, örgütte zorlu bir hedef için çaba sarf edip işletmenin başarısına önemli katkı sağlarlar (Leiter ve Bakker, 2010:1). İşle bütünleşme kişinin işi ile ilgili rol, sorumluluk, görev, vb. tüm özelliklerini kapsamaktadır. İşle bütünleşmenin öncül ve sonuçlarının incelendiği pek çok çalışma mevcuttur (Kodden ve Groenveld, 2019; Arslan ve Demir, 2017; Erkal, 2019; Biswas ve Bhatnagar, 2013). Božac, Sušanj ve Besim (2017) otel çalışanları ile gerçekleştirdikleri araştırmada çalışanların işle bütünleşme düzeylerinin en önemli belirleyicisinin kişi-örgüt uyumu olduğunu ortaya koymuşlardır.

Kişi-örgüt uyumu birey ve örgütün değerleri arasındaki uyumdur (Van Vianen ve De Pater, 2012; Kristof Brown vd., 2005). Bu değerlerin uyuşması kişinin organizasyona olan ilgisini arttırır (Kristof, 1996; Cable ve Edwards, 2004). Leiter ve Bakker (2010) çalışanların, değerlerinin uyuştuğu ya da örgüte getirdiği değerlere yanit veren örgütleri tercih ettiklerini belirtmektedir. Kişi-örgüt uyumu, öncelikle kişilerin iş ve örgüt seçiminde önemli ölçütlerden birisi olmakla birlikte sonrasında kişinin, iş hayatındaki tutum ve davranışlarını etkileyen önemli bir unsurdur. Araştırmada kişi-örgüt uyumunun işle bütünleşme üzerinde pozitif yönde ve anlamlı etkisi bulunmuştur. Buna göre çalışanların örgüt ile uyum düzeyleri arttıkça işle bütünleşme düzeyleri artmaktadır. Benzer şekilde literatürdeki araştırmalarda (Sortheix vd., 2013; Rahmadani ve Sebayang, 2017; Hamid ve Yahya, 2011; Peng vd., 2014; Saks ve Gruman, 2011; Biswas ve Bhatnagar, 2013) kişi-örgüt uyumunun işle bütünleşmeyi pozitif yönde etkilediği tespit edilmiştir. Peng vd. (2014) çalışmalarında kişi örgüt uyumu ile işle bütünleşme arasında $(r=0,59 ; p<0,01)$ yüksek düzeyde korelasyon tespit etmişlerdir.

Katılımcıların kişi-örgüt uyumu düzeyleri $($ ort=3,25) hizmet sektöründe gerçekleştirilen araştırmaların ortalamaları ile yakınlık göstermektedir. Kılıç ve Yener (2015) bankacılık sektörü çalışanlarının kişi-örgüt uyumu düzeylerinin ortalamasını 3,55 olarak, Tanrıverdi ve Guliyeva (2018) konaklama işletmelerinde çalışanların kişi-örgüt uyumu düzeylerinin ortalamasını 3,83 olarak tespit etmiştir.

Araştırmanın diğer bulgularına göre kadın çalışanların kişi-örgüt uyumu düzeyleri erkek çalışanlardan daha yüksektir. Benzer şekilde Aydoğan Güleryüz ve Aydıntan (2020) çalışmalarında kadın çalışanların örgütleri ile uyum düzeylerinin erkek çalışanlardan daha yüksek olduğunu tespit etmişlerdir. Araştırmada çalışanların medeni durumlarının kişi-örgüt uyumu düzeylerinde anlamlı farklılık yarattığı ve bekar çalışanların örgüt uyumunun evli çalışanlardan daha yüksek olduğu tespit edilmiştir. Türe vd. (2019) hemşireler üzerine yaptıkları çalışmada farklı olarak medeni durumun kişi-örgüt uyumu düzeylerinde farklılık yaratmadığını tespit etmişlerdir. Bekar çalışanların işe yoğunlaşma düzeyleri evli çalışanlardan daha yüksektir.

Araştırmada çalışanların eğitim düzeylerinin çalışanların göre kişi-örgüt uyumu düzeyleri ( $F=5,766 ; p<0,05)$, zindelik $(F=2,976 ; p<0,05)$, adanma $(F=4,341 ; p<0,05)$ ve yoğunlaşma $(F=1,260 ; p<0,05)$ düzeylerinin farklılık gösterdiği bulgulanmıştır. Sonuçlara göre lisans mezunu çalışanların kişi-örgüt uyumu, zindelik, adanma ve yoğunlaşma düzeyleri daha yüksektir. Çalışmada ayrıca katılımcıların işyerinde çalışma sürelerine göre adanma düzeyleri $(\mathrm{F}=10,891 ; \mathrm{p}<0,01)$ ve yoğunlaşma düzeylerinin $(\mathrm{F}=4,666 ; \mathrm{p}<0,05)$ istatistiki olarak anlamlı farklılık gösterdiği tespit edilmiştir. Çalışmada literatürden (Aydoğan Güleryüz ve Aydıntan, 2020) farklı olarak işyerinde çalışma süreleri ile kişi-örgüt uyumu düzeyleri arasında anlamlı bir farklılık tespit edilmemiştir.

Sonuç olarak kişi-örgüt uyumu işle bütünleşme düzeyini arttırmakta ve işle bütünleşme bireysel ve örgütsel düzeyde birçok olumlu sonuç doğurmaktadır. Kişi-örgüt uyumu ve işle bütünleşmenin sağlandığı örgütlerde iş memnuniyeti ve performans artacak, çalışanların örgüte bağ lılığı artacak, çalışan stresi azalacaktır. Bu çıtılarda özellikle hizmet sektörü açısından oldukça önemlidir. 
$\mathrm{Bu}$ çalışmanın hizmet sektöründe çalışanlar üzerinde yapılmış bir uygulama olarak literatüre önemli katkısının yanı sıra bazı sınırlılıkları da vardır. Bu araştırma sadece birinci veri kaynağı olarak anket kullanılarak gerçekleştirilmiştir. Gelecekteki araştırmalar nitel yöntemler (görüşme tekniği vb.) kullanılarak daha kapsamlı veri elde ederek gerçekleştirilebilir. Kişi-örgüt uyumunu ölçmede gözlemlenen değişken sayısı sınırlı olarak gerçekleştirilmiştir, daha sonra gerçekleştirilecek araştırmalarda faktör sayısı artırılabilir. Araştırmanın bir diğer kısıtı belli bölgedeki belli çalışanlara yönelik olarak gerçekleştirilmiş olmasıdır. Farklı bölgelerde ve farklı çalışanlar üzerinde araştırma tekrarlanabilir ve karşılaştırılabilir yeni bulgular sağlanabilir.

\section{KAYNAKÇA}

Akbaş, T. T. (2011). Algılanan kişi-örgüt uyumunun örgütsel vatandaşlık davranışları üzerindeki etkisi: görgül bir araştırma, Çanakkale Onsekiz Mart Üniversitesi İ̈BF Yönetim Bilimleri Dergisi, 9 (1), 53-81.

Aksay, K. ve Yasım, Y. K. (2016). Kişi-örgüt uyumunun örgütsel sinizm üzerindeki etkisi: kamu çalışanları örneği, Journal of International Social Research, 9(43), 1602-1611.

Altunışık, R., Coşkun, R., Bayraktaroğlu, S. ve Yıldırım, E. (2010). Sosyal bilimlerde araştırma yöntemleri, Sakarya: Sakarya Yayıncilık.

Arı, S. (2011). Örgüt ikliminin işle bütünleşme üzerine etksi ve bir uygulama, Yayınlanmamış Yüksek Lisans Tezi, İstanbul Üniversitesi Sosyal Bilimler Üniversitesi, İstanbul.

Arslan, E. T. ve Demir, H. (2017). İşe angaje olma ve iş tatmini arasındaki ilişki: hekim ve hemşireler üzerine nicel bir araştırma, Yönetim ve Ekonomi, 24(2), 371-389.

Atçıŏlu, E. (2018). Okulların etkililik düzeyleri ile çalışanların işe angaje olma düzeyleri arasındaki ilişki, Yayınlanmamış Yüksek Lisans tezi, Sütçü İmam Üniversitesi Sosyal Bilimler Enstitisü, Kahramanmaraş.

Aydoğan Güleryüz, E. ve Aydıntan, B. (2020). Kişi-örgüt uyumu ve örgüt kültürü arasındaki ilişki, bankacılık sektöründe bir uygulama, Uluslararası Sağlık Yönetimi ve Stratejileri Araştırma Dergisi, 6(1), 51-78.

Baransel, A. (1979). Çağdaş Yönetim Düşüncesinin Evrimi, Klasik ve Neo-Klasik Yönetim ve Örgüt Teorileri, Cilt 1, İstanbul, Fatih Yayınevi.

Baş Atik, Z. (2018). Öğretmenlerin işle bütünleşme düzeylerinin beş faktör kişilik özellikleri, iş doyumu ve öznel iyi oluşla ilişkisi, Yayımlanmamış Yüksek Lisans Tezi, Karadeniz Teknik Üniversitesi Eğitim Bilimleri Enstitüsü, Trabzon.

Bayramlık, H., Bayık, M. E. ve Güney, G. (2015). Kişi-örgüt uyumunun iş tatmini üzerine etkisi: Ankara ilinde iş makineleri sektörü işgörenleri üzerinde bir uygulama, Kara Harp Okulu Bilim Dergisi, 25(2), $1-28$.

Bentler, P. M. (1990). Comparative fit indexes in structural models, Psychological Bulletin, 107, 238-246.

Biswas, S. ve Bhatnagar, J. (2013). Mediator analysis of employee engagement: role of perceived organizational support, P-O fit, organizational commitment and job satisfaction, Research, 38(1), 2740 .

Byrne, B. M. and Campbell, T. L. (1999), Cross-cultural comparisons and the presumption of equivalent measurement and theoretical structure: a look beneath the surface, Journal of Cross Cultural Psychology, 30(5), 555-574.

Cable, M. D. and Judge, T. A. (1994). Pay-preferences and job search decisions: a person-organization fit perspective, Personal Psychology, 47, 317-349.

Cable, D. M. and Judge, T. A. (1995). The role of person-organization fit in organizational selection decisions, (CAHRS Working Paper 95-07), Ithaca, NY: Cornell University, School of Industrial and Labor Relations Center for Advanced Human Resource Studies. 
Cable, D. M. ve Edwards, J.R. (2004). Complementary and supplementary fit: a theoretical and empirical integration, Journal of Applied Psychology, 89(5), 822-834.

Chatman, J. A. (1991). Matching people and organizations: selection and socialization in public accounting firms, Administrative Science Quarterly, 36(3), 459-484.

Erkal, P. (2019). İç girişimciliğin işe tutkunluğa etkisinde birey-örgüt uyumunun aracılık rolü, İşletme Araştırmaları Dergisi, 11(4), 2812-2823.

Ertemli, H. B. (2011). İş-aile ve aile-iş çatışmalarının işe cezbolma üzerindeki etkisine yönelik bir uygulama, Yayınlanmamış Yüksek Lisans Tezi, Yıldız Teknik Üniversitesi Sosyal Bilimler Enstitüsü, İstanbul.

Eryılmaz, A. ve Doğan, T. (2012). İş yaşamında öznel iyi oluş: Ultrecht işe bağlllık ölçeğinin psikometrik niteliklerinin incelenmesi, Klinik Psikiyatri, 15, 49-55.

Fornell, C. and Larcker, D. F. (1981). Evaluating structural equation models with unobservable variables and measurement error, Journal of Marketing Research, 18(1), 39-50.

George, D. and Mallery, P. (2001). SPSS for Windows step by step: a simple guide and reference 10.0 update, Needham Heights, MA: Allyn\&Bacon.

Gonan Božac, M., Sušanj, Z., and Besim, A. (2017). Attitudinal and behavioral outcomes of PO fit and work engagement in hotel staff. Organizational Cultures: An International Journal, 17(1), 21-38.

Greguras, G. J. and Diefendorff, J. M. (2009). Different fits satisfy different needs: linking personenvironment fit to employee commitment and performance using self-determination theory, Journal of Applied Psychology, 94(2), 465-477.

Gün, F. (2017). Öğretmenlerin eğitime inanma ve işle bütünleşme düzeyleri arasındaki ilişkinin incelenmesi, Journal of Theoretical Educational Science, 10(4), 408-431.

Gündüz, B., Çapri, B. ve Gökçakan, Z. (2013). Mesleki tükenmişlik, işle bütünleşme ve iş doyumu arasındaki ilişkilerin incelenmesi, Eğitim Bilimleri Araştırmaları Dergisi, 3(1), 29-49.

Hamid, S. N. A. and Yahya, K. K. (2011). Relationship between person-job fit and person-organization fit on employees' work engagement: a study among engineers in semiconductor companies in Malaysia, In Annual Conferenc on Innovation in Business and Management London, 6(9), 1-30.

Jin, M. H., McDonald, B. and Park, J. (2018). Person-organization fit and turnover intention: exploring the mediating role of employee followership and job satisfaction through conservation of resources theory, Review of Public Personnel Administration, 38(2), 167-192.

Kahn, W. A. (1990). Psychological conditions of personal engagement and disengagement at work, Academy of Management Journal, 33(4), 692-724.

Kılıç, K. C. ve Yener, D. (2015). Birey-örgüt ve birey-iş uyumunun çalışanların iş tutumlarına etkisi: Adana ilinde bankacılık sektöründe çalışanlar üzerine bir araştırma, Ç. U. Sosyal Bilimler Enstitüsü Dergisi, 24(1), 161-174.

Kim, S. (2012). Does person-organization fit matter in the pablic-sector? Testing the mediating effect of person-organization fit in the relationship between public service motivation and work attitudes, Public Administration Review, 72(6), 830-840.

Kim, T. Y., Aryee, S., Loi, R. and Kim, S. P. (2013). Person organization fit and employee outcomes: test of a social Exchange model, The International Journal of Human Resource Management, 24(19), 3719-3737.

Kline, R. B. (1998). Principles and practice of structural equation modeling, New York: The Guilford Press.

Kodden, B. and Groenveld, B. (2019). The mediating effect of work engagement on the relationship between person-organization fit and knowledge sharing. Journal of Applied Business and Economics, 21(8), 32-48.

Krejcie, R. V. and Morgan, D. W. (1970). Determining sample size for research activities. Educational and Psychological Measurement, 30 (3), 607-610. 
Kristof, A. L. (1996). Person-organization fit: an integrative review of its conceptualizations, measurement, and implications, Personnel Psychology, 49(1), 1-49.

Kristof-Brown, A. L., Zimmerman, R. D. and Johnson, E. C. (2005). Concequences of individualists at work: a meta-analysis of person-job, person-organization, person-group, and person-supervisor fit, Personnel Psychology, 58(2), 281-342.

Lauver, K. J. and Kristof-Brown, A. (2001). Distinguishing between employees' perceptions of person-job and person-organization fit, Journal of Vocational Behavior, 59(3), 454-470.

Leiter, M. P. and Bakker, A. B. (2010). Work engagement: Introduction. In A. B. Bakker (Ed.) \& M. P. Leiter, Work engagement: A handbook of essential theory and research, pp. 1-9. NewYork, US: Psychology Press.

Leung, A. and Chaturvedi, S. (2011). Linking the fits, fitting the links: connecting different types of P-O fit to attitudinal outcomes, Journal of Vocational Behavior, 79(2), 391-402.

Maslach C. and Leiter, M. P. (2008). The truth about burnout: how organizations cause personel stres and what to do about it, San Francisco, Jossey-Bass.

Maslach, C. and Goldberg, J. (1998). Prevention of burnout: new perspectives, Applied and Preventive Psychology, 7(1), 63-74.

Memon, M. A., Salleh, R., Nordin, S. M., Cheah, J. H., Ting, H., and Chuah, F. (2018). Person-organisation fit and turnover intention: the mediating role of work engagement, Journal of Management Development, 37(3), 285-298.

Netemeyer, R. G., Boles, J. S., McKee, D. O. and McMurrian, R. (1997). An investigation into the antecedents of organizational citizenship behaviors in a personel selling context, The Journal of Marketing, 61(3), 85-98.

Özdemir, O., Birer, İ. ve Akkoç, İ. (2017). Lider desteği ve örgütsel adalet algısının iş performansına etkisinde kişi-örgüt uyumunun aracilık rolü, Toros Üniversitesi IISBF Sosyal Bilimler Dergisi, 6(10), 77-106.

Özgen, F. Ö. ve Turunç, Ö. (2017). Örgütsel adalet-sinizm ilişkisinde kişi örgüt uyumunun rolü: eğitim sektöründe bir araştırma, Uluslararası İktisadi ve İdari Bilimler Dergisi, 3(2), 80-96.

Pekdemir, İ., Koçoğlu, M. ve Çetin Gürkan, G. (2013). Birey-örgüt uyumunun açıkça konuşma davranışı üzerindeki etkisinde algılanan yönetici desteğinin aracılık rolü: MBA öğrencilerine yönelik bir araştırma, İ.Ü. İşletme Fakültesi İ̧̧letme İktisadi Enstitüsü Yönetim Dergisi, 24(75), 83-104.

Peng, J. C., Lee, Y. L. and Park, J. (2018). Person-organization fit and turnover intention: exploring the mediating effect of work engagement and the moderating effect of demand-ability fit, Journal of Nursing Research, 22(1), 1-11.

Polatçı, S. ve Cindiloğlu, M. (2013). Kişi-örgüt uyumunun örgütsel vatandaşlık davranışına etkisi: duygusal bağlllı̆̆ın aracılık rolü, Süleyman Demirel Üniversitesi İ̈BF Dergisi, 18(3), 299-318.

Polatçı, S., Kadir, A. ve Tinaz, Z. (2007). Tükenmişlik sendromu ve demografik özelliklerin tükenmişlik üzerine etkisi: Tokat orta öğretim kurumlarında bir analiz, Sosyal ve Ekonomik Araştırmalar Dergisi, Emin Kayar Özel Sayısl, 7, 1-22.

Rahmadani, V. G. and Sebayang, I. R. (2017). The influence of person-organization fit and person-job fit on work engagement among policemen in sumetera utara, International Journal of Management Science and Business Administration, 4(1), 45-51.

Rynes, S. L., Brown, K. G. and Golbert, A. E. (2002). Seven common misconceptians about human resource practices: reesearch fidings versus practitioner beliefs, Academy of Management Executive, 16(3), 92103.

Saks, A. M. and Gruman, J. A. (2011). Getting newcomers engaged: the role of socialization tactics, Journal of Managerial Psychology, 26(5), 383-402. 
Schaufeli, W. B. and Bakker, A. B. (2004). Job demands, job resources, and their relationship with burnout and engagement: a multi sample study, Journalo f Organizational Behavior, 25(3), 293-315.

Schaufeli, W. B., Salanova, M., Gonzalez-Roma, V. and Bakker, A. B. (2002). The measurement of engagement and burnout: a two sample confirmatory factor analytic approach, Journal of Happiness Studies, 3(1), 71-92.

Schermelleh-Engel, K., Moosbrugger, H. and Müller, H. (2003). Evaluating the fit of structural equation models: test of significance and descriptive googness of fit measures, Methods of Psychological Research-Online, 8(2), 23-74.

Schneider, B., Goldstiein, H. W. and Smith, D. B. (1995). The ASA framework: an update, Personnel Psychology, 48(4), 747-773.

Sortheix, F. M., Dietrich, J., Chow, A. and Salmela-Aro, K. (2013). The role of career values for work engagement during the transition to working life, Journal of Vocational Behavior, 83(3), 466-475.

Tanrıverdi, H. ve Guliyeva, D. (2018). Konaklama işletmelerinde kişi-örgüt uyumu ve duygusal emek düzeyleri arasındaki ilişkinin analizi, International Journal of Tourism, Economics and Business Sciences (IJTEBS), 2(2), 467-475.

Turgut, T. (2011). Çalışmaya tutkunluk: iş yükü, esnek çalışma saatleri, yönetici desteği ve iş-aile çatışması ile ilişkileri, Atatürk Üniversitesi İktisadi ve İdari Bilimler Dergisi, 25(3-4), 155-179.

Turunç, Ö. ve Çelik, M. (2012). İş tatmini- kişi-ögüt uyumu ve amire güven- kişi-örgüt uyumu ilişkisinde dağıtım adaletinin düzenleyici rolü, "İडs, Güç" Endüstri İlişkileri ve İnsan Kaynakları Dergisi, 14(2), 5778.

Türe Yılmaz, A., Kök Eren, H. ve Yıldırım, A. (2019). Hemşirelerde yöneticiye güvenin kişi-örgüt uyumuna etkisi, Afyon Kocatepe Üniversitesi Sosyal Bilimler Dergisi, 21(4), 1205-1215.

Ulutaş, M. K., Kalkan, M., Bozkurt, A. ve Çetinkaya, Ö. (2015). Birey-örgüt uyumunun iş doyumu ve örgüte bağll1ı üzerine etkisi, ISGUC The Journal of Industrial Relations and Human Resources, 17(1), 138-160.

Van Vianen, A. E. M. ve De Pater, I. E. (2012). Content and development of newcomer person-organization fit: an agenda for future research, In C. R. Wanberg (Ed.), The Oxford handbook of organizational socialization, pp. 139-157, Oxford: Oxford University Press.

Vatansever Durmaz, İ. B. (2019). Havayolu yolcu taşımacılığı sektöründe algılanan stres ve işle bütünleşme arasındaki ilişkinin işten ayrılma kararına etkisi, Al Farabi Uluslararası Sosyal Bilimler Dergisi, 3(1), 5969.

Yücel, İ. ve Çekinkaya, B. (2016). Birey-örgüt uyumu ile örgütsel bağlllık arasındaki ilişkide cinsiyetin rolü: Kayseri örneği, Aksaray Üniversitesi İ̈BF Dergisi, 8, 31-45.

Zhang, Y., Ying, G. and Peng, L. (2005). Moderating effects of P-O Fit in turnover intentizon model: a case of foreign pharmaceutical companies in China, Nankai Business Review, 8(3), 37-41. 